\title{
THE FIRST RECORDS OF PRINCE VLADIMIR IN SOURCES
}

ABSTRACT. The paper attempts to answer the question of the first records of Prince Vladimir in historical sources. Up to now it has been considered that he was first mentioned in the work "A Synopsis of Byzantine History" by John Skylitzes. However, Henri Grégoire and Raoul De Keyser indicate that the prince was mentioned in "The Song of Roland" ("La Chanson de Roland") as rei flurit, i.e., as the Blessed King. This epic originates from the spring of 1085 in Salerno, which was under the Norman rule at the time. This author agrees and supports the thesis by identifying a great number of concepts which refer to the Balkans (geographically, ethnically). It is believed that the Normans obtained information about the Balkans and Prince Vladimir while they held Dyrrhachium from 1081 to 1085.

KeYwords: The Song of Roland; Prince Vladimir; Dioclea; The Chronicles of the Priest of Dioclea; Dyrrhachium.

Reliable dating and interpretation of historical sources is extremely significant for gaining knowledge on historical events and personages as well as the representation of them at the time when these sources appeared. The further into the past the topic of scien-

\footnotetext{
djekicdj@ptt.rs

Rad je nastao kao rezultat rada na projektu departmana za istoriju Filozofskog fakulteta u Nišu Istorija, razvoj i perspektive, broj 100/1-10-2-01, 2021. godine.

This paper was submitted on September $12^{\text {th }}, 2021$ and accepted for publication at the meeting of the Editorial Board held on November $16^{\text {th }}, 2011$.
} 
tific research is, the fewer the sources are, the scarcer the data and the more comprehensive the critique of the sources during the verification of data should be. The question of the first records of the Prince of Dioclea Vladimir can be studied through the comparative analysis of medieval history, epic poetry, chronicles, church books and topography.

When we refer to the first mention of Prince Vladimir, we should stress that the topic of our study is the first records of Prince Vladimir which have reached us but we are also interested to find out which data the sources bring and how they are related to other data which have survived. The most significant historical source on Prince Vladimir is "The Chronicles of the Priest of Dioclea" ("The Chronicles..." further in the text), the only source offering data on his whole life and the origin of his cult. Some data on Vladimir as a

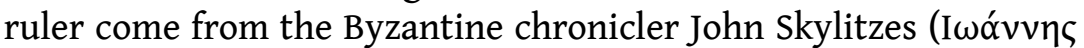
$\Sigma \kappa v \lambda i \tau \zeta \eta \varsigma)$, who lived in the $11^{\text {th }}$ century, i.e. Bishop Michael of Devol, who wrote amendments to Skylitzes' text. The prince is also mentioned in "The Book of Boril" (or "Boril Synodic"), compiled in 1211, while he was first mentioned as Saint Jovan Vladimir in the Menaion, dating from the end of the $13^{\text {th }}$ century or the beginning of the $14^{\text {th }}$ century.

It is uncertain what time "The Chronicles of the Priest of Dioclea" dates from (Кунчер, 2009, p. 138). ${ }^{2}$ However, dating this document is important to determine the time when the data about Prince Vladimir, which must have existed by that time, were included in it. Namely, "The Chronicles..." itself specifically refers to the existence of librum gestorum on Vladimir, which was added to "The Chronicles..." in its abridged form (Кунчер, 2009, p. 138). Most authors say that "The Chronicles..." dates from the mid- $12^{\text {th }}$ century or a few decades later (Кунчер, 2009, pp. 25-26). ${ }^{3}$ Exceptionally, only a few authors connect its origin to a later period. Mijušković, who disqualifies it as a historical source and qualifies it as a work of literature, thinks it derives from the $14^{\text {th }}$ century (1988, pp. 12-88). Živković believes that the work was written in two parts, the first one originating from the end of the $13^{\text {th }}$ century, and the other from the beginning of the $14^{\text {th }}$ century (Кунчер, 2009, pp. 339-378). According to Solange Bujan, "The Chronicles..." was written in the

2 In literature it is also referred to as the Bar genealogy (Радојчић, 1936, pp. 128).

3 These pages give a detailed list of the authors who date "The Chronicles..." to this period, so they won't be repeated here. 
17th century - in 1601 by Mavro Orbini (2011, pp. 65-80). Consequently, the earliest dating of "The Chronicles..." is the mid- $12^{\text {th }}$ century.

Another work having an abundance of data is A Synopsis of Byzantine History by John Skylitzes, which has to be mentioned along with the work of Michael of Devol, who didn't write his piece as an individual work but as an amendment to Skylitzes' (Thurn, 1973, pp. 353-354, 359; Ферлуга, 1966, pp. 117-118). Recent literature states that Skylitzes' work originates from the end of the $11^{\text {th }}$ century, while Michael of Devol's interpolation from the beginning of the 12th century (Пириватрић, 2018, p. 16, 21), i.e., 1118 (Јововић, 2017, pp. 22). Skylitzes writes that Vladimir, whose title he did not mention, ruled over Tribalia and the neighbouring areas of Serbia and that he was Emperor Samuel's son-in-law. He says that Vladimir was a just, calm and virtuous person. While he was the ruler, the situation in Dyrrhachium was peaceful. This sentence was amended by Michael of Devol, who states the name of Samuel's daughter, Theodorites. Further in his text, Skylitzes says that Vladimir trusted Ivan Vladislav's promises sent to him through David, Archbishop of Bulgaria, resulting in him losing his life by the order of Emperor Ivan Vladislav. On the other hand, Michael of Devol says that the archbishop was not David but John.

St Jovan Vladimir was mentioned in Boril's Synodic, i.e., the Synodic of the Bulgarian Emperor Boril, written in 1211. Namely, in the church service held once a year, on the first Sunday of the Easter fast (the Sunday of Orthodoxy), the patrons of Orthodoxy were mentioned. All Bulgarian rulers were mentioned in the Synodic, starting with Michael (Boris) in the $9^{\text {th }}$ century all the way to Samuel, Gavril Radomir, Vladimir and the last one Ivan Vladislav (Божилов et al., 2010, pp. 311, 333). From all these sources it can be concluded that the oldest source on Prince Vladimir - the Holy King Jovan Vladimir was the work by John Skylitzes from the $11^{\text {th }}$ century.

However, we believe that there is an even older source which mentions Prince Vladimir. Namely, during the 1930s, Henri Grégoire and Raoul De Keyser indicated that Prince Vladimir was mentioned in "The Song on Roland". ${ }^{4}$ They thought that he was King Flurit, rei Fluri, mentioned in Verse 3211. They believed that the Normans learnt about him during their stay in Dyrrhachium (Grégoire \& Keyser, 1939, p. 298). They stated that there were no allusions whatsoever to the conflicts related to the period from 
1096 to 1099, i.e., the First Crusade, and that this led them to conclude that the epic must have originated from the period before that, i.e., that the oldest version of "The Song on Roland" dates from the spring of 1085 in Salerno, a city significant for the Normans (Grégoire \& Keyser, 1939, pp. 300-301). Norman soldiers gained knowledge about the Balkans during the First Norman Invasion of the Balkans in 1081-1085 (Grégoire \& Keyser, 1939, pp. 287). Božidar Kovačević also believes that the description of Baligan's army gives 'a vague memory' of the combats of Normans with Byzantium from 1081 till 1085 (1940, pp. 396-397; 1960, pp. 486-488).

When mentioning King Vladimir, apart from the title, the author of "The Song of Roland" also mentions the land that it rules over in Verse 3208 - the land "Dès Chériant entres qu'en Val-Marchis", i.e. "From Cheriant to Val-Marchis". Grégoire and De Keyser believe that "Cheriant" is the same as "Charzanes", mentioned by Anna Komnene, i.e., that this term refers to the river Arzen (1939, pp. 297). In Albanian this river is called the Erzen today (Theotokis, 2014, p. 24). It flows from southern to central Albania. Its source is south of Tirana, then it turns to the south, north of Elbasan, but still south of Tirana. Then it continues to flow towards Dyrrhachium, but at that point it turns and flows into the Adriatic Sea just above Dyrrhachium. The other term, the other border which determines the land ruled by Vladimir is "Val-Marchis". These authors think that the term "Val" refers to the river, while the term "Marchis" refers to the river Morača $(1939$, pp. 279, 298). The river Morača springs west of Kolašin, goes down to the south, passes through Podgorica and flows into Skadar Lake (Радовановић \& al., 1974, p. 69). This would mean that the state ruled by Vladimir stretched from the river Arzen in the south to the river Morača in the north. In the west most probably was the Adriatic Sea, while the eastern borders were not mentioned.

of course, we can pose the question how we can be sure that this mention refers to Dioclea and Prince Vladimir, or this part of Europe at all, since "The Song of Roland" is about the defeat of Charles the Great on August $15^{\text {th }} 778$ on his way back from the Iberi-

4 Literature refers to this work as both a poem and an epic. We will refer to it as an epic. Henri Grégoire (1881-1964), Belgian historian and linguist, expert in Byzantium, member of The Royal Academy of Science, Letters and Fine Arts of Belgium (https://www.peoplevisions.com/henri-gregoire/), Raoul De Keyser, librarian of the Royal Library of Belgium, Grégoire's son-in-law (- 1945), killed by the Nazis (News from Belgium, Volume 5, 14th July 1945, p. 171). 
an Peninsula, while Roland, to whom this epic is dedicated, is a hero and knight of Charles the Great. So, "The Song of Roland" talks about a completely different part of Europe.

Beside pointing out that Flurit was Prince Vladimir, Grégoire and De Keyser point to a series of other terms, like toponyms, peoples related to the Balkans, which make it more probable that Flurit was Prince Vladimir indeed. Since the connection of this epic with Dyrrhachium has been established, we are going to discuss all the terms which are related to either Dyrrhachium or Prince Vladimir.

The greatest number of the terms related to the Balkans, which we are interested in, was mentioned when the composition of Baligan's army was given, the army which fought the war against Charles the Great (Драшковић, 1981, pp. 111-113). ${ }^{5}$

The terms related to the geography, ethnicity and states are mentioned there. In respect to geography, many cities, capes, rivers and lands are mentioned. First, the city Butrinto ("Butentrot", Verse 3220) on the Adriatic coast across the island of Corfu was mentioned (Brault, 1997, p. 196). ${ }^{6}$ The next one was "Jericho" in Verse 3228 , which is sometimes connected in literature with the city of the same name in the Holy Land, which would mean that the epic must have been written after the Crusades (Brault, 1997, p. 196). However, Jericho, city in Epirus, was also mentioned by Anna Komninos in her Alexiad, which could be another proof what this was the same city mentioned in "The Song of Roland". Today this city is called Orikum and is situated deep in the Bay of Vlorë. The people of Kanina (i.e. the people of "Canelius" in Verses 3269 and 3238) were also mentioned, which definitely refers to the people of the city of Kanina. The city of Kanina was mentioned in the First Ohrid Epistle of Basil II in 1019 (Grégoire \& Keyser, 1939, pp. 270278; Brault, 1997, pp. 197, 198; Коматина, 2016, p. 95). ${ }^{7}$ Then, two capes were mentioned: Pali (as "Balide" in Verse 3230 and "Baldise" in Verse 3255), which are situated north of Dyrrhachium, and the cape of Glos (as "Gloz" in Verse 3230 and "Galosa" in Verse 3255),

5 All the terms from the epic in their original from are quoted as presented in Grégoire and De Keyser, since we did not have the original available.

6 Brault presents an English translation which is not always identical to the original used by Grégoire and De Keyser.

7 Grégoire, De Keyser 1939, pp. 270-274, 275-278; Brault 1997, pp. 197, 198; Komatina 2016, p. 95. The provinces of Jericho and Kanina, together with the province of Dioclea, are mentioned in the chrysobull of the Byzantine emperor Alexius III Angelos to the Republic of Venice in 1198 (Komatina 2016, p. 85). 
which is situated south of Dyrrhachium (Grégoire \& Keyser, 1939, pp. 279-280; Brault, 1997, pp. 197, 199). Beside the river Arzen, which we have already located, the river Vojuša ("Val Fuit" in Verses 2238-3239) (Brault, 1997, p. 197), which flows into the Adriatic Sea northwest of Valona (Grégoire \& Keyser, 1939, pp. 278-279), was mentioned. The mention of Little Prespa, lake mentioned as "malp'se" in Verse 3253 and as "Malpreis" in Verse 3285 (Brault, 1997, pp. 199, 200; Grégoire \& Keyser, 1939, pp. 296, 313) is particularly significant because Samuel's court was on the island within the lake (Ђекић, 2017, pp. 37-38, 40, 44-46).

Ethnically, the Serbs were mentioned as "Sorbres" and as "Sorz" in Verse 3226. These two terms are considered by Grégoire and De Keyser to be synonymous. Among other people, we will mention Slovs ("Esclavoz" in Verse 3225) and Greeks ("Gros" in Verse 3229), who are not difficult to identify judging from the form of the terms. The mention of "Blos", i.e. "Blas" in some manuscripts, in Verse 3224 is considered the first mention of the Vlachs in the literature of Western Europe (Grégoire \& Keyser, 1939, pp. 287, 290-291; Brault, 1997, p. 197). One people was described as Samuel's people ("la gene Samuel") in Verse 3244 (Grégoire \& Keyser, 1939, p. 287, 291). ${ }^{8}$ The epic mentions other peoples too: Hongrois, Bulgares and Romains (Verses 2922 and 2923). The term Hongrois definitely refers to the Hungarians, the term Romain to the Byzantians, while the term Bulgares is self-explanatory (Драшковић, 1981, p. 102). The fact that Samuel's people was separately mentioned, and Bulgarians separately, indicates that the author knew the situation in the Balkans extremely well, i.e., that he knew the ethnical differences between these two empires pretty well, although Samuel claimed his entitlement to the Bulgarian Empire and became Emperor based on that. We need to mention that the epic also mentions the toponym "la terre d'Ebire" in Verse 3995, which refers to the territory of Epirus (Grégoire \& Keyser, 1939, pp. 298-300). That this description of Baligan's army refers to Robert Guiscard's campaign to Dyrrhachium in 1081, as Grégoire and De Keyser claim, can be supported by the verses saying that the people of Kanana came through the Val Fuit, i.e., through the river Vojuša (Verses 22383239) (Brault, 1997, p. 196). That the people of Kanana crossed the river Vojuša, since Kanina was situated south of it, means that they

8 Radojičić translates it as "narod Samuilov" [eng."Samuel's people"], Kovačević as "Samuilov puk" [eng. "Samuel's mass"], (1967, p. 30; 1940, p. 395; 1960, p. 485). 
had to move northwards, i.e., towards Dyrrhachium, which confirms the hypothesis that "The Song of Roland" is related to Robert Guiscard's campaign to Dyrrhachium (Grégoire \& Keyser, 1939, p. 279).

Baligant is considered to be George Palaiologos, Byzantine commander who fought against Robert Guiscard. It is believed that the name Kanabeus refers to Emperor Alexis I Komninos, George's brother-in-law, but the epic, unaware of family relationships, turns him into his brother (Grégoire \& Keyser, 1939, pp. 294-295). The epic also mentions Malprimes as Baligant's son. Marvix, commander of the Byzantine fleet, who took Bari from the Normans in 1066, was recognized as Malprimes (Grégoire \& Keyser, 1939, pp. 296297). This proves that apart from the knowledge about the 10811085 wars, the authors of the epic were familiar with the sources from earlier periods as well. Beside the author's contemporaries, among the historical personages from the Balkans, only Samuel and Vladimir were mentioned by the author, as we have already shown.

Grégoire and De Keyser say that the form "Flurit" was created because the Normans found the name Vladimir exotic, so they changed it into Flurit. That Flurit refers to Vladimir was also supported by Radojčić. He says that the Bulgarian researcher Tomov wrote in the dictionary of "The Song of Roland" that the term flur (flore) symbolized heavenly bliss. Thus, Flurit in Old French, close to the Romance language, would also mean 'blessed' in Dioclea. This epithet, with the same meaning, is mentioned in "The Chronicles..." as well - "beati Vladimiri" - the blessed Vladimir. This shows that already at that time, before 1081, Prince Vladimir had his cult and his saintly epithet - blessed (Кунчер, 2009, pp. 138-139; Радојичић, 1967, pp. 30-32).

Grégoire and De Keyser believe that the Normans found out about Vladimir during their stay in Dyrrhachium (1939, p. 297). The question is why Prince Vladimir was so important for Dyrrhachium that the Normans must have heard about him. The answer to this question can be found in "The Chronicles of the Priest of Dioclea" and John Skylitzes's work.

"The Chronicles..." says that the Bulgarian Emperor Samuel gave Vladimir "totamque terram Duracenorum", i.e. "the whole territory of Dyrrhachium“ (Кунчер, 2009, p. 130; Мијушковић, 1988, p. 127). This does not mean, however, that he had power over the city of Dyrrhachium itself. This fact has been disputed due to another story related to Vladimir and Cossara - the story about Ashot and 
Miroslava. Namely, Samuel gave one of his daughters to Ashot (just as he gave the other to Vladimir) and gave him Dyrrhachium to rule. Ashot took the side of Byzantium and surrendered the city to it. However, "The Chronicles..." mentions the territory of Dyrrhachium - not the city itself but its region (Ђекић, 2018, p. 24, 33). That Vladimir ruled the region of Dyrrhachium can be concluded from what Skylitzes writes: while Vladimir ruled Tribalia and Serbia, the situation in Dyrrhachium was calm (Ферлуга, 1966a, pp. 117-118). According to Pirivatrić, Skylitzes says that at the time of the conflict between Emperor Samuel and Emperor Basil, Vladimir did not take sides nor did he actively take part in the conflict (Пириватрић, 1998, р. 115). This refers to the period from 1005, when Dyrrhachium was again under the power of Byzantium (Коматина, 2012, p. 172). However, this still was not a reason enough to make Prince Vladimir, who ruled the region of Dyrrhachium, well known and mentioned about 70 years after his death, making the territory under his rule well-known too.

Namely, "The Chronicles..." quotes that after he had murdered Vladimir and allowed Cossara to take his body to Krajina and bury it there, the newly-crowned Bulgarian emperor, Vladimir's killer, Vladislav decided to take Vladimir's land and the city of Dyrrhachium. During the siege Vladislav was visited by an angel - Prince Vladimir dressed as a knight. Having recognized him, Vladislav called for help and tried to run away. However, the angel caught and killed him "corpore et anima." Vladislav, who ordered that Vladimir be killed during a lunch, was killed at a dinner, becoming, as "The Chronicles..." says, "ut anelus Satanae efficeretur" (Кунчер, 2009, pp. 136-139; Ђекић, 2018, р. 71).

Vengeance is banned in both the old and the New Testaments. ${ }^{9}$ So, the angel appearing as Vladimir could not be vengeful. His role in this act must be of a different kind. He killed Vladislav not to revenge himself but to protect the city of Dyrrhachium from the one who was going to conquer it. In this way, he became the protector of the city of Dyrrhachium! Earlier he had already protected his own people when he surrendered to Samuel on Mount Oblik in order to save his soldiers' lives (Кунчер, 2009, pp. 136-139). With Vladislav's death, Dyrrhachium was protected from infidels and the angel of Satan. This was done by the one who, while ruling the

9 In the Old Testament: III Moses, 19, 18. In the New Testament: Gospel According to Matthew 5, 38-40. Furthermore, God promises punishment to those who take revenge: The Cry of Jeremiah, 3, 60, 64 . 
region, had earlier been on good terms with Dyrrhachium. Furthermore, those relationships must have been more than good since he became the patron of Dyrrhachium. Otherwise, the murder of Vladislav, committed by an angel of God in the image of Vladimir, could not be understood nor explained. This refutes the view that Vladimir was buried in the vicinity of Skadar and that his relics were taken to the south at the beginning of the $13^{\text {th }}$ century (Ђекић, 2018, p. 71).

We can ask where the authors of "The Song..." obtained their data about Prince Vladimir from. We can assume that there must have been a literary work through which the Normans learnt about him while they were in Dyrrhachium. What can prove this assumption? First, the only persons from the Balkans mentioned in the epic who were not the contemporaries of "The Song..." were Samuel and Vladimir. Both perished about 70 years before the epic was written. At that time, there were a lot of historically more significant personages than Vladimir, such as Byzantine Emperor Basil II (9761025). The authors of the epic knew about Samuel's court at Mala Prespa. It must be admitted that it is surprising that Mala Prespa, rather than Velika Prespa, Ohrid or Skadar Lake, which were far bigger and better known, was mentioned. This fact can only be explained if they knew that Samuel's court was there, the fact mentioned in the story about Vladimir. That Samuel was well-known to the authors of the epic can also be supported by referring to 'Samuel's people' as different from the Bulgarians, as we have shown. Besides, they mentioned his saintly epithet - the blessed, which they turned into his name. This also shows that the saintly cult of Vladimir existed. Using the title 'king' next to his name, i.e. calling him "rei Flurit", also indicates that the title of 'prince', which he had most likely had, was replaced with the superior title of 'king', which was later recorded in literature. It is considered that he was made king in 1070s, when the Prince of Dioclea Michael was proclaimed king (Бекић, 2018, p. 32).

Thus, they could know these data only if they had read the hagiography of Vladimir or some similar work, where Samuel, his people and especially Mala Prespa were mentioned. That work must have been kept and read in Dyrrhachium, the patron of which Vladimir had already become.

Does literature accept this view of Grégoire and De Keyser? Božidar Kovačević agrees that the description of Baligant's army "vaguely reminds" of the combats of the Normans with Byzantium 
from 1081 to 1085 (1940, pp. 396-397; 1960, pp. 486-488). Đorđe Sp. Radojčić also supports their opinion in several of his papers. He believes that the epic mentions the Slovs, Serbians, Samuel's people and finally King Vladimir as Flurit. We have also mentioned his view how Vladimir became Flurit, i.e., what Flurit means. He agrees that the epic was written in 1085 in Salerno, while the Normans could have heard about Vladimir during their stay in Dyrrhachium (1967, pp. 27-32) Then he develops their idea about Samuel's people in a separate paper (1971, pp. 111-117). Radojčić indicates that Grégoire and De Keyser connect Vladimir to Florimon through a novel written by Emon de Varen. In this work Florimon is the son of a Dyrrhachium duke who marries the niece of the Bulgarian king Kamdiobras. The king's court was on the island of Celée (Radojičić, 1965, pp. 528-535). Radojčić will quote these two researchers once again - referring to their belief that Vladimir was Flurit, that the name means 'Blessed'; he will also discuss Florimon, the time of the origin of "The Chronicles..." and the like (1967, pp. 2). Next, we should mention Antonije Farčić, who quotes these two researchers in his paper on the life of Saint King Vladimir, proving that Vladimir really had the king's title, as he was referred to in "The Song on Roland" (1969, pp. 73-79). Finally, in his paper "St Jovan Vladimir in Literature and Tradition of the Serbian People in the 20th Century", Božidar Zarković reminds of Grégoire and De Keyser's views and their influence on the historiography of Serbia (2016, pp. 228-229).

How are these data related to those presented in other sources? "The Chronicles..." does not state the borders of Vladimir's state but does mention some geographical terms which refer to the territory under his rule. The first one is the župa (district) Oblik (Tarboš), stretching south of Skadar Lake along the right bank of the river Bojana (Кунчер, 2009, p. 126-127; Живковић, 2006, p. 68; Мишић, 2014, p. 22). We have already explained the term 'the Dyrrhachium region'. Tribalia and Serbia refer to the Serbian state. The term Krajina is mentioned as the place where Cossara took her dead husband's body and buried it in the Church of St Mary "tulitque denique corpus eius et asportavit in loco, qui Craini dicitur, ubi curia eius fuit, et in ecclesia sanctae Mariae recondidit." Apart from the fact that Krajina was a bordering area, it is not possible to determine its precise position (Бекић, 2018, pp. 46-47). Therefore, it can be assumed that the border went from skadar Lake to Dyrrhachium. 
The epic says that the river Morača, which flows into Skadar Lake, was the northern border. As we have said, the river Arzen flows into the Adriatic Sea north of Dyrrhachium but it springs south of Dyrrhachium, near Tirana. Thus, the data in "The Chronicles..." and in the epic are almost identical. As there is no evidence that the author of "The Chronicles..." read and quoted data from the epic, this can only mean that the data presented in these two sources are valid. This would also explain why "The Chronicles..." says that Prince Vladimir was buried in Krajina. The area around Elbasan would really be a bordering area.

In the end, we can conclude that "The Song of Roland" presents valid data on Vladimir. First, it proves that Vladimir had become a saint with the title 'blessed' before the epic was written, that he became king for the sake of making the royal crown of King Michael sacred, and that the territory under his rule could be identified and that it, roughly speaking, matches the territory mentioned in "The Chronicles...".

Judging from the data analyzed by Grégoire and De Keyser, as well as Kovačević, Radojčić and this author, we can conclude that "The Song of Roland" is the oldest source on Prince Vladimir.

Brault, G. J. (1997). La Chanson de Roland. Philadephia: The Pennsylvania State University.

Thurn, H. (1973). Ioannis Scylitzae Synopsis Historiarum. Corpus fntium historiae Byzantinae, v. 5. Berlin and New York: Walter de Gruyter.

Божилов, И., Тотоманова, А., М. Билярски, И. (2010). Борилов Синодик. София: ПАМ Пъблишинг Къмпани ООД.

Драшковић, В. (1981). Песма о Роланgу. Старофранцуски спев, превод, предговор и објашњење Владо Драшковић. Београд: Народна књига.

Кунчер, Д. (2009). Gesta regum Sclavorum, књига I. Приредила и превела Драгана Кучнер. Београд - Никшић: Историјски институт - Манастир Острог.

Мијушковић, С. (1988). Љеӣойuс ӣoӣa Дукљанина. Предговор, пропратни текстови, превод Славко Мијушковић. Београд: Просвета, Српска књижевна задруга.

Радовановић, М., Мастиловић, М., Стојановић, Д., Живковић, М., Ђурђевић, Б., Дејановић, Н. (1974). Геоірафски айлас. Уреднички одбор М. Радовановић, М. Мастиловић, Д. Стојановић,. М. Живковић, Б. Ђурђевић, Н. Дејановић, Београд: Издање Завода за картографију „Геокарта“. 


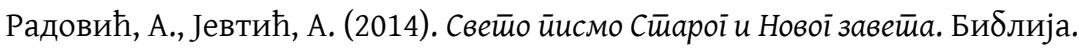
Превео Стари завет митрополит црногорско - приморски Амфилохије (Радовић), умировљеи епископ захумско - херцеговачки Атанасије (Јевтић), Нови завет Комисија Светога Архијерејског Синода Српске Православне Цркве, Београд: Свети архијерејски синод 2014.

Ферлуга, J. (1966). Јован Скилища. У: Г. Острогорски и Ф. Баришић, (ур.).

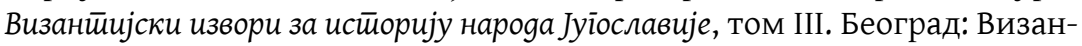
толошки институт САНУ, 51-172.

REFERENCES Bujan, S. (2011). Orbinijevo izdanje „Ljetopisa popa Dukljanina“: povijesni falsifikat. Radovi Zavoda za hrvatsku povijest Filozofskoga fakulteta Sveučilišta u Zagrebu, vol. 43, no. 1, 65-80.

Farčić, A. (1969): Žitije sv. kralja Vladimira, Boka, 1, 73-79.

Grégoire, H., de Keyser, R. (1939). La chanson de Roland et Byzance ou de l'utilité du grec pour les romanistes. Byzantion, XIV, 265-316.

Radojičić, Sp. Đ. (1965). „Un poème Yougoslave du XIe siècle: les “Gesta” ou exploits de Vladimir, prince de Dioclée“, Byzantion XXXV, 528-535.

Theotokis, G. (2014). Norman Campaigns in the Balkans, 1081-1108. Woodbridge: Boydell.

Ђекић, Ђ. (2017). Свети Јован Владимир - од кнеза до светог краља. У: У сйомен и славу Свейої Јована Влаgимира, књ. 5. Цетиње: Митрополија црногорско - приморска - ИИУ Светигора.

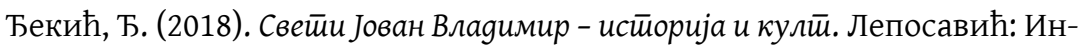
ститут за српску културу Лепосавић.

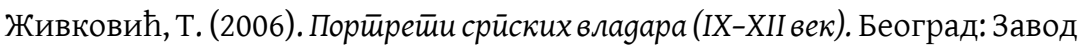
за уџбенике и наставна средства.

Зарковић, Б. (2016). Свети Јован Владимир у литератури и традицији српског народа у ХХ веку, Црквне сӣуguје, 13, 209-236.

Јововић, В. (2017). Свети Јован Владимир - Извори. Свевиђе, 107, 21-23.

Ковачевић, Б. (1940). „Песма о Роланду“ и Словени. Срӣски књижевни іласник, нова серија књ. 6 (60), 394-397.

Ковачевић, Б. (1960). Стари трагови. Сусрет̄u, 5, 484-488.

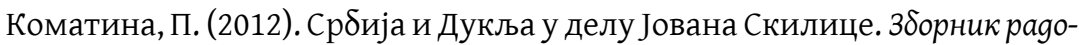

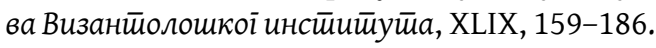

Коматина, П. (2016). област Вагенитија и епископија Св. Климента,

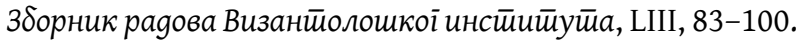

Мишић, С. (2014). Исӣоријска їеоірафија срӣских земаља оg 6. gо ӣоловине 16. века, Београд: Магелан Прес.

Пириватрић, С. (1998). Самуилова gржава. Београд: Византолошки институт САНУ књ. 21. 
Пириватрић, С. (2018). Кнез Владимир и Диоклитија између Римско-византијског и Бугарског царства. У: У сйомен и славу Све̄̄ої Јована Влаgими$p a$, књ. 6/1. Међународни научни скуп „Свети Јован Владимир кроз вјекове - историја и предање (1016-2016)“ Бар, 15-17. септембра 2016. године, 13-41.

Радојичић, Сп. Ђ. (1967). Ђорђе Сп. Радојичић, Ейска йесма јуїословенска из ХІ века, Књижевна збивања и стварања код Срба у средњем веку и у турско доба, Нови Сад. Матица српска, 27-32.

Радојичић, Сп. Ђ. (1967). Легенда о Владимиру и Косари - њени видови ХІ-ХІХ века, Баїgaла, 96-97, 2.

Радојчић, Н. (1936). Друштвено и државно уређење код Срба у раном средњем веку - према Барском родослову. Гласник Скойскої научноі gру-

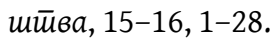

Радојчић, Сп. Ђ. (1971). Ѓорѓе Сп. Радоичиќ, „La gent Samouel (народот на Самоил)“ во песната за Роланд (La chanson de Rolland), 1000 loguни og во-

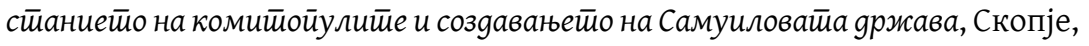
111-117.

ЂОРЂЕ Н. ЂЕКИЋ

УНИВЕРЗИТЕТ У НИШУ, ФИЛОЗОФСКИ ФАКУЛТЕТ

ДЕПАРТМАН ЗА ИСТОРИЈУ

РЕЗИМЕ

О ПРВОМ ПОМЕНУ КНЕЗА ВЛАДИМИРА У ИЗВОРИМА

Рад настоји да одговори на питање првог помена кнеза Владимира - Светог краља Владимира у историјским изворима. До сада се сматрало да је то учињено у делу Кратка историја Јована

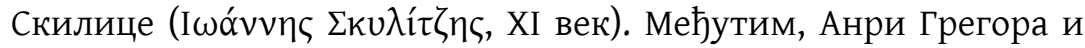
Раул да Кајзер доказују да се кнез спомиње у Ейу о Роланgу који је настао у пролеће 1085. године у Салерну, тада под влашћу Нормана. Ей га спомиње као "rei Flurit", који је владао "Dès Chériant entres qu'en Val-Marchis", односно од реке Аоös (Војуша) до Мораче. Поред тога, поменути аутори своју тезу поткрепљују идентификовањем великог број појмова који се односе на Балкан (географски, етнички), што нас наводи да прихватимо њихову претпоставку као исправну. Постављајући питање како је аутор $E \bar{u} a$ дошао до података о краљу Владимиру, налазимо одговор у чињеници да су Нормани боравили у Драчу од 1081. до 1085. године и да је краљ Владимир био заштитник Драча. Назвавши га "rei Flurit", што значи Блажени краљ, указује на то да је његов 
култ већ успостављен, да је стекао епитет "блажени" и да је од кнеза напредовао до краља. Сви наведени подаци указују да је Eū o Роланgу најстарији извор у коме се помиње кнез Владимир Свети краљ Владимир.

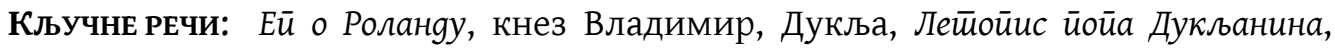
Драч.

Овај чланак је објављен и дистрибуира се под лиценцом Creative Commons Ауторство-Некомерцијално Међународна 4.0 (СC BY-NC 4.0 |

https://creativecommons.org/licenses/by-nc/4.0/).

This paper is published and distributed under the terms and conditions of the Creative Commons Attribution-NonCommercial International 4.0 licence (CC BY-NC 4.0 | https://creativecommons.org/licenses/by-nc/4.0/). 